\section{Intraarticular Administration of}

Dexamethasone after Mesenchymal

Stem Cells Implantation Does Not

Improve Significantly the Treatment

of Preestablished Full-Thickness

Chondral Defect in a Rabbit Model
Cartilage

4(2) I44-152

(C) The Author(s) 2013

Reprints and permission:

sagepub.com/journalsPermissions.nav DOI: 10.1 I 177/I9476035I2472696

http://cart.sagepub.com

@SAGE

\author{
Maximiliano Espinosa',Alex Vaisman ${ }^{1,2}$, Nicolas Nazal', David Figueroa², Marcela \\ Gallegos ${ }^{2}$, and Paulette Conget'
}

\begin{abstract}
Objective: The aim of this study was to evaluate the contribution to hyaline cartilage regeneration of dexamethasone intraarticular administration after autologous mesenchymal stem cells (MSCs) implantation into a preestablished knee full-thickness chondral defect. Design: Full-thickness chondral defects of $4.5 \times 4.5 \mathrm{~mm}^{2}$ were surgically made in both medial femoral condyles of adult male New Zealand rabbits. Two weeks later, autologous ex vivo expanded bone marrow-derived MSCs were embedded in hyaluronic acid and implanted into the chondral defects. Immediately and every week after the intervention, dexamethasone $0.25 \mathrm{mg} / \mathrm{kg}$ was intraarticularly administered (MSC/dexa-treated group). Six weeks after MSC transplantation, the animals were euthanized and condyles were characterized molecularly according to aggrecan, collagen type II, and collagen type I gene expression (quantitative reverse transcriptase-polymerase chain reaction) and histologically (hematoxylin-eosin staining). Data of MSC/dexa-treated condyles were compared with untreated, dexa-treated, MSCtreated, or normal unlesioned condyles. Results: The ratio between collagen type II expression versus collagen type I expression in MSC/dexa-treated condyles was higher than one, even though the group mean value was not statistically different from that of untreated defects. Histological changes were observed between MSC/dexa-treated and untreated defects mainly in surface regularity and in hyaline matrix abundance. However, International Cartilage Repair Society score analysis did not support robust differences between those groups. Conclusion: Intraarticular administration of dexamethasone after autologous MSC implantation into a preestablished full-thickness chondral defect does not contribute significantly to the regeneration of a tissue with molecular and histological characteristics identical to hyaline cartilage.
\end{abstract}

\title{
Keywords
}

hyaline cartilage regeneration, full-thickness chondral defect, mesenchymal stem cells, dexamethasone

\section{Introduction}

Chondral injuries are common and result in significant health care costs. ${ }^{1}$ Because of the poor regeneration potential of articular cartilage, mild injuries can lead to progressive lesion, resulting in the impairment of joint capacity to absorb and to distribute mechanical loads. ${ }^{2}$ Multiple techniques such as subcondral drilling, microfractures, osteochondral grafting, and autologous chondrocyte implants have been used for the treatment of articular cartilage defects. However, none of these strategies have been able to regenerate hyaline cartilage. ${ }^{3-5}$ Tissue engineering represents a promising strategy to treat articular cartilage defects. This approach consists in the use of an interactive triad among cells, scaffolds, and bioactive molecules aimed to promote tissue regeneration. ${ }^{6}$

'Instituto de Ciencias, Facultad de Medicina Clinica Alemana, Universidad del Desarrollo, Santiago, Chile

${ }^{2}$ Clinica Alemana, Santiago, Chile

\section{Corresponding Author:}

Paulette Conget, Instituto de Ciencias, Facultad de Medicina Clínica Alemana, Universidad del Desarrollo, Av. Las Condes 12,438, Lo Barnechea, Santiago 7710162, Chile

Email: pconget@udd.cl 


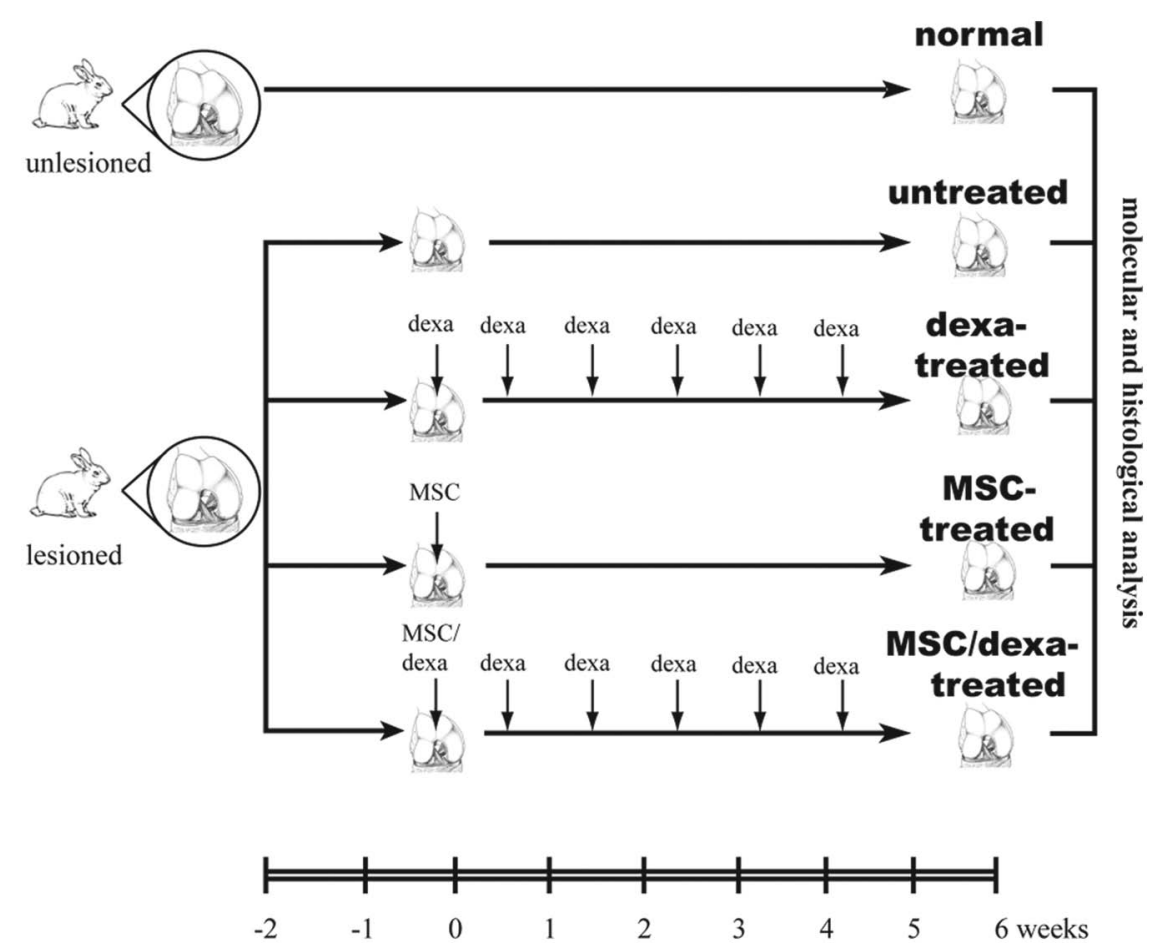

Figure I. Study design. Surgical full-thickness chondral defects were established in the medial femoral condyles of adult New Zealand male rabbits. Two weeks later, defects were not treated (untreated group, $n=1 \mathrm{I}$ ) or treated with dexamethasone (dexa-treated group, $n=12$ ), mesenchymal stem cells (MSCs) (MSC-treated group, $n=5$ ), or MSCs and dexamethasone (MSC/dexa-treated group, $n=15$ ). Six weeks after the initiation of the interventions, condyles were analyzed molecularly and histologically. Condyles without lesions were used as control (normal group, $n=\mathrm{II}$ ).

Mesenchymal stem cells, also referred to as multipotent mesenchymal stromal cells (MSCs), are an attractive tool for cartilage tissue engineering as they are relatively easy to isolate and to expand in culture under conditions in which they maintain their potential to differentiate into chondrocytes. ${ }^{7-10}$ Hence, several attempts to treat chondral defects with MSCs have been reported. ${ }^{11-14}$ In the first one published, MSCs embedded in a gel of collagen type I were locally implanted into just established, full-thickness chondral injuries. ${ }^{11}$ Four weeks after the intervention, a tissue with characteristics similar to hyaline cartilage was observed. However, 24 weeks later the tissue formed in the area of the defect was stiffer, less compliant, and thinner than the adjacent host cartilage. At present, none of the reported strategies have been able to significantly improve this result, even when using scaffolds or bioactive molecules. ${ }^{15}$

In a lesioned joint, the pro-inflammatory environment is a major adverse condition for effective regeneration of hyaline cartilage. ${ }^{16}$ Pro-inflammatory cytokines, such interleukin-1 and tumor necrosis factor- $\alpha$ prevent the chondrogenic differentiation of MSCs, inhibit the expression of collagen type II, and stimulate the expression of collagen type I in chondrocytes and alter the degradation of extracellular matrix components. ${ }^{17-19}$ Dexamethasone is an ideal candidate to modify the microenvironment of lesioned joint in order to promote cartilage regeneration as it (a) acts as an anti-inflammatory signal, ${ }^{20}$ (b) induces MSC chondrogenic differentiation, ${ }^{21-23}$ (c) stimulates aggrecan gene expression in MSCs, ${ }^{21,24}$ and (d) maintains collagen type II synthesis in chondrocytes. ${ }^{25}$

The aim of this study was to evaluate, in a rabbit model, the contribution to hyaline cartilage regeneration of dexamethasone intraarticular administration after autologous MSC implantation into a preestablished knee full-thickness chondral defect.

\section{Methods}

\section{Study Design (see Fig. I)}

\section{Animals}

Twenty-seven New Zealand male rabbits (3 month old, 2.5$3.5 \mathrm{~kg}$ ) were used in this study. Animals were housed at constant temperature and humidity, with a $12: 12$ h lightdark cycle and with unrestricted access to a standard diet and water. The research protocol was reviewed and approved by the Ethic Committee of Faculty of Medicine Clinica Alemana, Universidad del Desarrollo. All procedures were 
carried out under anesthesia, with $35 \mathrm{mg} / \mathrm{kg}$ ketamine and $5 \mathrm{mg} / \mathrm{kg}$ xylazine, both administered intramuscularly. Perioperative antibiotics and analgesics were administered to all experimental animals.

\section{Establishment of Full-Thickness Chondral Defect}

Full-thickness defect was created in the weightbearing area of the femoral condyle by making a lateral longitudinal parapatellar arthrotomy. The articular surface was exposed by lateral dislocation of the patellae. With a $3-\mathrm{mm}$ osteotome, a standardized defect of $4.5 \mathrm{~mm}$ in length, $4.5 \mathrm{~mm}$ in width, and full-thickness in depth was created. Chondral defects were performed in 43 condyles that were randomly distributed to four experimental groups.

\section{MSC Isolation, Expansion, and Characterization}

From both iliac crests, bone marrow was aspirated with a 19-gauge needle that was fastened to a $10-\mathrm{mL}$ syringe containing $1 \mathrm{~mL}$ heparin $250 \mathrm{U}$ (Laboratorio Chile, Santiago, Chile). After centrifugation, nucleated cells were seeded at a density of $1 \times 10^{6} / \mathrm{cm}^{2}$ in $\alpha$-MEM culture medium supplemented with $10 \%$ fetal bovine serum and $40 \mathrm{mg} / \mathrm{mL}$ gentamicin (Sanderson Laboratory, Santiago, Chile). The next day nonadherent cells were discarded by medium replacement. Thereafter, the medium was changed every 4 days. Cultures were maintained at $37{ }^{\circ} \mathrm{C}$ in an atmosphere of air: $\mathrm{CO}_{2}$ (95\%:5\%). The cells were further subcultured by trypsinization and used at passage 3. Expanded cells were characterized according to their adipogenic, osteogenic, and chondrogenic differentiation potential as previously described. ${ }^{7}$

\section{MSC Embedding in Hyaluronic Acid (HA)}

The day of the intervention, $1 \times 10^{6}$ MSCs were collected by detachment with $0.25 \%$ trypsin containing $2.6 \mathrm{mM}$ ethylenediaminetetraacetic acid (EDTA; Gibco, Burlington, Ontario, Canada), washed, centrifuged, and resuspended in $20 \mu \mathrm{L}$ physiologic solution containing $5 \%$ autologous rabbit serum. Three micrograms of HA (Sigma Aldrich, Steinheim, Germany) was added to the cells and incubated, at room temperature, until a viscous suspension (hydrogel) was formed.

\section{Chondral Defect Interventions}

Two weeks after their establishment, full-thickness chondral defects were randomized and the experimental interventions were initiated. One group of defects received an implant of $1 \times 10^{6}$ MSCs embedded in HA and weekly intraarticular dexamethasone $0.25 \mathrm{mg} / \mathrm{kg}$ (MSC/dexatreated group, $n=15$ ). Other groups received only the implant of $1 \times 10^{6}$ MSCs embedded in HA (MSC-treated group, $n=5$ ) or weekly intraarticular dexamethasone $0.25 \mathrm{mg} / \mathrm{kg}$ (dexa-treated group, $n=12$ ) or no treatment (untreated group, $n=11$ ). The number of cells administered was chosen based on a previous study. ${ }^{12}$ With regard to the dose of dexamethasone, it was scaled from dose currently used in humans. The number of condyles per experimental group was defined to obtain an $\alpha$ value of .05 and a power of $90 \%$ in quantitative analysis. Also, to reduce the number of animals sacrificed and considering that our main aim was to assess the impact of the combined strategy (MSCs plus dexamethasone) against the untreated group, we included fewer animals in the MSC-treated group. Before the implantation, any reparative tissue found at the chondral lesion was debrided with an osteotome. Then, injury was filled with the hydrogel that was gently pressed up to no material leak. Finally, arthrotomies were closed in the deep layer with 4.0 Vycril suture and in the skin with 3.0 Nylon. Animals were kept in separate cages and allowed to walk freely. Six weeks postintervention initiation (8 weeks postlesion), the rabbits were killed by an intravenous overdose of pentobarbital, and condyles were dissected and analyzed. Unlesioned condyles were used as controls (normal group, $n=11$ ).

\section{Aggrecan, Collagen Type II, and Collagen Type I mRNA Quantification}

Condyles were frozen and pulverized with a mortar. The powder thus obtained was dissolved in $1 \mathrm{~mL}$ of Trizol reagent (Invitrogen, Carlsbad CA) and incubated for 30 minutes at room temperature. Total RNA was extracted with $300 \mu \mathrm{L}$ of chloroform and precipitated with $500 \mu \mathrm{L}$ of isopropanol for $24 \mathrm{~h}$ at $-20{ }^{\circ} \mathrm{C}$. After washing with $75 \%$ ethanol, the RNA pellet was dried and dissolved in $11 \mu \mathrm{L}$ of DMPC water. RNA concentration was determined spectrophotometrically at $260 \mathrm{~nm}$. First strand cDNA was reverse transcribed from $1 \mu \mathrm{g}$ of RNA, incubating with $1 \mu \mathrm{g}$ oligodT (Tib Molbiol, Berlin, Germany) for 10 minutes at $70{ }^{\circ} \mathrm{C}$ at a final volume of $12 \mu \mathrm{L}$. Eight microliters of a mix containing $1 \mu \mathrm{L}$ dNTPs $10 \mathrm{nM}$ (Fermentas Life Sciences, Hanover, MD), buffer M-MLV 1× (Tris-HCl $50 \mathrm{nM}$ [pH 8.3], KCl 7 $\mathrm{mM}, \mathrm{MgCl}_{2} 3 \mathrm{mM}$, DTT $\left.10 \mathrm{mM}\right), 1 \mu \mathrm{L}$ M-MLV reverse transcriptase $200 \mathrm{U} / \mu \mathrm{L}$ (Promega, Madison, WI), RNAsin inhibitor 1× (Promega, Madison, WI), and DMPC water was added to a final volume of $20 \mu \mathrm{L}$. Polymerase chain reaction (PCR) amplification was carried out in a reaction volume of $10 \mu \mathrm{L}$ containing $0.15 \mu \mathrm{g}$ of cDNA, $0.8 \mu \mathrm{L}$ $\mathrm{MgCl}_{2} 25 \mathrm{mM}$, each of the sense and anti-sense primers at $0.5 \mu \mathrm{M}$ (Genética y Tecnología Ltda, Santiago, Chile), and $1 \mu \mathrm{L}$ FastStart DNA Master SYBR Green I 10× (FastStart Taq DNA polymerase, dNTPs, SYBR Green I, $\mathrm{MgCl}_{2}$ $10 \mathrm{nM}$ ) (Roche). Rabbit aggrecan, collagen type II (col2a1), collagen type I (colla1), and gapdh primers used are shown in Table 1. PCR conditions are described in Table 2. For 
Table I. Primers and Amplicons Used in the Study

\begin{tabular}{|c|c|c|c|c|c|c|}
\hline \multirow[b]{2}{*}{ Gene } & \multirow[b]{2}{*}{ GenBank Access Number } & \multirow[b]{2}{*}{ Sense $\left(5^{\prime} \rightarrow 3^{\prime}\right)$} & \multirow[b]{2}{*}{ Antisense $\left(5^{\prime} \rightarrow 3^{\prime}\right)$} & \multicolumn{2}{|c|}{ Amplicon } & \multirow[b]{2}{*}{ Reference } \\
\hline & & & & Size (bp) & $\operatorname{Tm}\left({ }^{\circ} \mathrm{C}\right)$ & \\
\hline Collagen II & D83228 & ACACTGCCAACGTCCAGATG & GTGATGTTCTGGGAGCССTC & 64 & 85 & 16 \\
\hline Collagen I & S61950 & TCССTTCСTTGATATTGCACCT & GGCCAACGTCCACATAGAATTC & 68 & 82 & 16 \\
\hline Gapdh & L2396। & GGTGAAGGTCGGAGTGAACG & AGTTAAAAGCAGCCCTGGTGAC & 65 & 83 & 16 \\
\hline
\end{tabular}

Table 2. Polymerase Chain Reaction Conditions

\begin{tabular}{lccc}
\hline Gene & Annealing & Extension & Cycle Number \\
\hline Collagen II & $62{ }^{\circ} \mathrm{C} ; 5 \mathrm{~s}$ & $72{ }^{\circ} \mathrm{C} ; 5 \mathrm{~s}$ & 45 \\
Collagen I & $56^{\circ} \mathrm{C} ; 5 \mathrm{~s}$ & $72^{\circ} \mathrm{C} ; 5 \mathrm{~s}$ & 45 \\
Gapdh & $57{ }^{\circ} \mathrm{C} ; 10 \mathrm{~s}$ & $72^{\circ} \mathrm{C} ; 5 \mathrm{~s}$ & 45 \\
\hline
\end{tabular}

each sample, the $\mathrm{Ct}$ value was determined as the cycle number at which all samples were in the exponential phase of amplification. The gene expression of aggrecan was standardized against gapdh RNA levels. The ratio between collagen type II and collagen type I was used as an indicator of hyaline versus fibrous cartilage. ${ }^{26}$

\section{Histological Analysis}

Condyles were fixed in formalin, decalcified in nitric acid, and embedded in paraffin. Ten-micrometer-thick sagital cross sections were cut. Sections were stained with hematoxylineosin. The samples were blindly evaluated by a trained pathologist and graded according to the International Cartilage Repair Society (ICRS) histological assessment of cartilage repair. ${ }^{27}$ The scale was composed of six categories, assigning a score to the most prominent feature on each sample.

\section{Statistical Analysis}

PCR results (means \pm standard deviations) were compared using ANOVA and Tukey posttest to prove statistical differences among groups. ICRS scores (medians) were compared using Mann-Whitney $U$ test to prove statistical differences between experimental versus normal and between treated versus untreated groups. Values of $P<0.05$ were considered statistically significant.

\section{Results}

\section{Characterization of Full-Thickness Chondral Defects before Their Intervention}

Two weeks after their establishment, full-thickness chondral defects were filled with a white, irregular, and opaque tissue. The margins between newly formed tissue and host cartilage were well recognizable, indicating that there was no integration between them (Fig. 2A). At histological level, cell distribution was disorganized and granulation tissue was observed in subchondral bone (Fig. 2B). Also, inflammatory infiltrate was evident.

\section{Hyaline versus Fibrous Cartilage Markers Expression after Chondral Defects Intervention}

Aggrecan is a marker of cartilage tissue. ${ }^{28}$ As seen in Figure 3A, no significant differences were observed in aggrecan expression between experimental groups. The ratio between collagen type II expression versus collagen type I expression is used as an indicator to distinguish between hyaline versus fibrous cartilage. ${ }^{26}$ Accordingly, this ratio was more than one in the normal group (1.47 \pm $0.16)$ and less than one in the untreated group $(1.03 \pm 0.08$, $P<0.05$ ) (Fig. 3B). In the case of MSC/dexa-treated defects, the mean group value was $1.15 \pm 0.21$. This increase was not statistically significant when compared with the untreated group or with the other treated groups.

\section{Histological Analysis after Chondral Defects Intervention}

As seen in Figure 4, normal condyles presented a regular surface with a hyaline matrix and chondrocytes organized in columns. The untreated group showed a mostly irregular surface with a hyaline matrix mixed with fibrocartilage. In the dexa-treated group, all samples presented an irregular cartilage surface, with a cell distribution predominantly disorganized. The MSC-treated group showed differences in surface criteria, ranging from samples with a smooth surface to others with an irregular surface (Fig. 4). In the MSC/ dexa-treated group, the surface of the tissue was mostly regular, with a hyaline matrix mixed with fibrocartilage in some areas. Cell distribution was irregular in this group; in some, condyles chondrocyte-like cells appeared organized in columns, whereas in others they appeared in clusters or were disorganized. Quantitative analysis of histological data showed that cell population viability, cartilage mineralization, and subchondral bone were unaltered in all groups. Nonetheless, surface, matrix, and cell distribution varied 


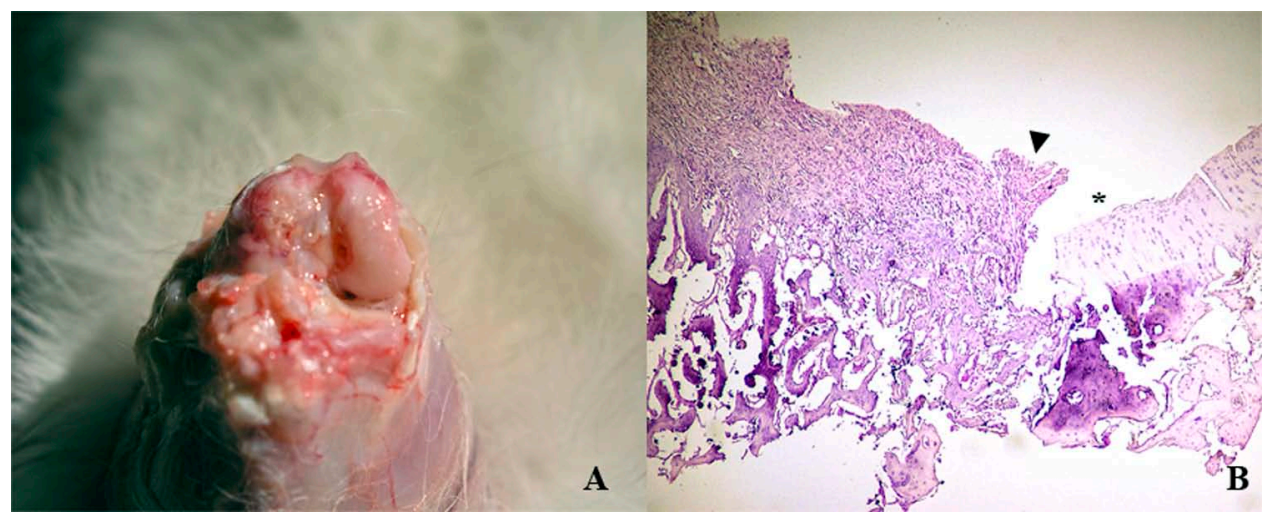

Figure 2. Characterization of full-thickness chondral defects before their intervention. Macroscopical (A) and histological (B) characteristics of the tissue formed 2 weeks after the establishment of full-thickness chondral defect. Arrow: border of the defect. Asterisk: normal surrounding cartilage. Data shown are representative of four sections (20x) per animal for for animals.

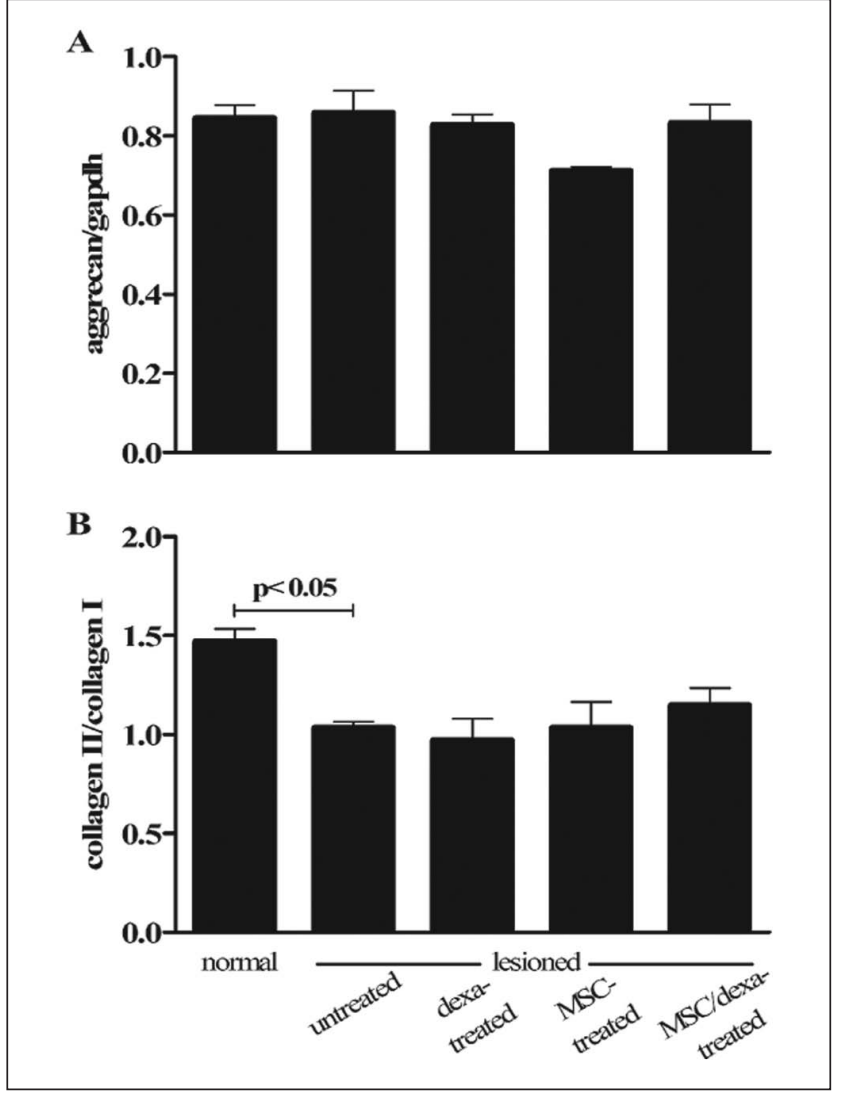

Figure 3. Hyaline versus fibrous cartilage markers expression after chondral defects intervention. Cartilage relative gene expression of aggrecan $(\mathbf{A})$ and collagen type II versus collagen type I (B) 6 weeks after the initiation of the interventions. Data correspond to group mean \pm standard deviation. Normal $(n=7)$, untreated $(n=7)$, dexa-treated $(n=5)$, MSC-treated $(n=3)$, and MSC/dexa-treated $(n=6)$. Only significant $P$ values are shown. $\mathrm{MSC}=$ mesenchymal stem cell. among them (Fig. 5). In these three categories, the normal group presented an ICRS score of 3 . When compared with the normal group, the untreated group showed a significant reduction in scores in the surface and matrix categories ( 3 vs. 0 and 3 vs. 2 , respectively; $P<0.05$ ). The MSC/dexatreated group showed a median score for surface category higher than that of the untreated group ( 3 vs. 0 ) and equal to that of the normal group (3 vs. 3 ). In the former case no statistical significance was proven. Dexa- and MSC-treated groups showed no significant improvement in surface and matrix scores when compared with the untreated group (0 and 1.5 vs. 0 , and 2 and 2 vs. 2). However, in the dexatreated group a significant impairment in cell distribution was observed against the normal group ( 0 vs. $3, P<0.05)$. The same was true for the MSC/dexa-treated group but to a lesser extent ( 2 vs. $3, P<0.05)$. At the end of the study period ( 8 weeks after chondral defect establishment), no evidence of inflammation was observed in the experimental groups.

\section{Discussion}

The cartilage regeneration potential of MSCs have been evaluated in several experimental models. ${ }^{11-14}$ In most of them the chondral defect was established in the troclear cartilage, an area of lower biomechanical demand than the weightbearing area of the femoral condyles. ${ }^{3}$ On the other hand, in previous reports the tested experimental intervention (treatment) has been performed during the same surgical procedure in which the chondral defect was established. It is well known that cartilage regeneration is affected by the biomechanical forces exerted on the articular surface as they modify the rates of synthesis and degradation of matrix proteins..$^{29,30}$ Together, in the clinical scenario there 


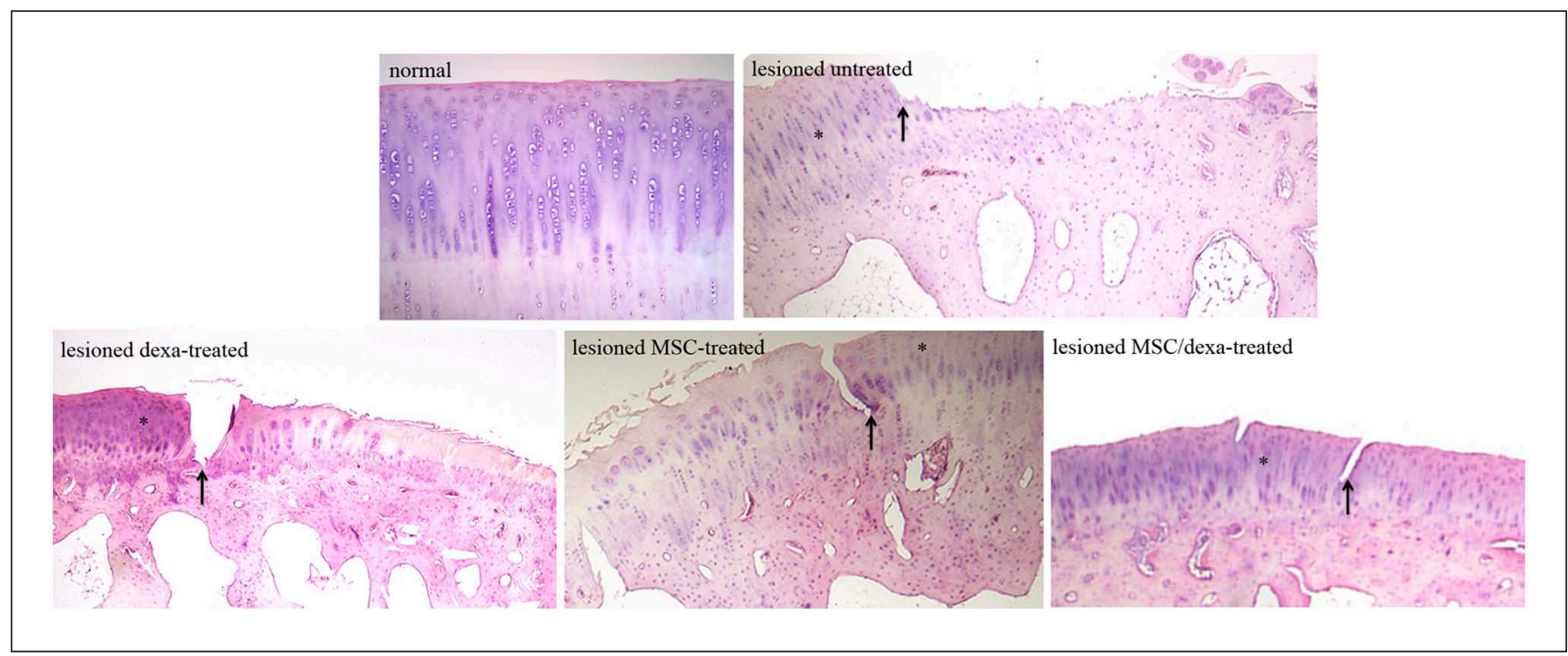

Figure 4. Qualitative histological analysis after chondral defects intervention. Cartilage histological analysis 6 weeks after the initiation of the interventions. Arrow: border of the defect. Asterisk: normal surrounding cartilage. Data shown are representative of four sections (20x) per animal (2-9).

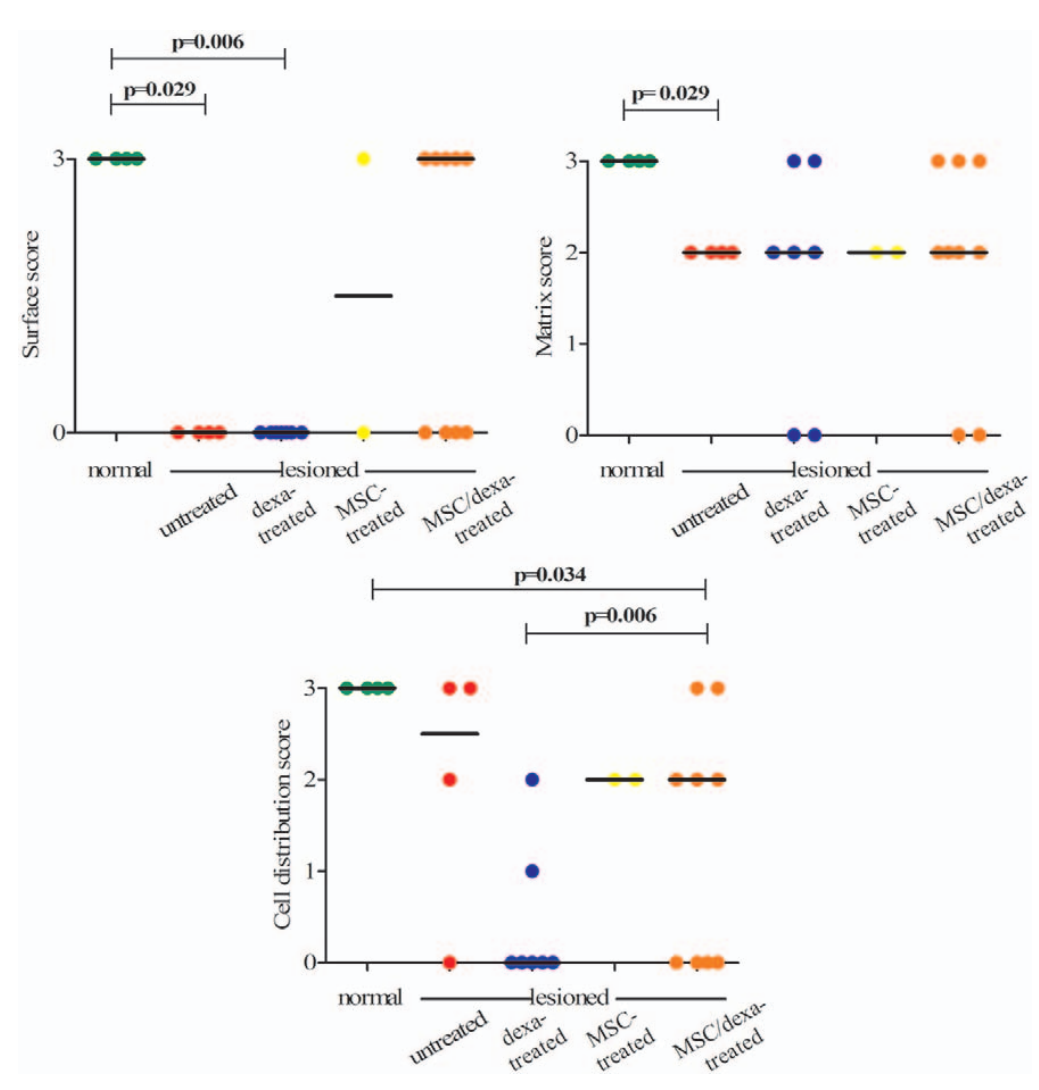

Figure 5. Quantitative histological analysis after chondral defects intervention. ICRS histological assessment of cartilage repair score was determined 6 weeks after the initiation of the interventions. For cell population viability, cartilage mineralization and subchondral bone categories the score was 3 , in all groups (not shown). For the shown categories, circles correspond to individual scores and horizontal line to group median score. Normal $(n=4)$, untreated $(n=4)$, dexa-treated $(n=7)$, MSC-treated $(n=2)$, and MSC/dexatreated $(n=9)$. Only significant $P$ values versus normal, or versus untreated group are shown. ICRS $=$ International Cartilage Repair Society; $\mathrm{MSC}=$ mesenchymal stem cell. 
is a latency time between the establishment of the lesion and its treatment. In our study, we evaluated whether the implantation of HA-embedded MSCs together with weekly intraarticular administration of dexamethasone contribute to hyaline cartilage regeneration in a preestablished fullthickness chondral defect in the knee joint. For this, in a first chirurgic procedure a chondral defect was generated in a high load bearing area of the medial femoral condyles. Two weeks later, in a second chirurgic procedure, the tested intervention was carried out. To minimize damage associated to the first surgery, when the chondral defect was established special care was taken to minimize soft tissue impair. Hence, the incision performed was restricted just to gain access to the articular cavity, the patella was partially dislocated, and only the medial condyle was exposed.

Despite this minimally invasive procedure, 2 weeks later the joint capsule and soft tissues were inflamed and fibrosis was evident at the suture site. The chondral defect was filled with a white, irregular, and opaque tissue, which needed to be removed prior to the intervention. In this experimental model no significant improvement in full-thickness chondral defects was observed when treated with autologous MSCs. In contrast, already published data claim that these cells contribute to cartilage regeneration. ${ }^{11-14}$ This discrepancy might be attributed to the fact that we implanted MSCs 2 weeks after chondral defect establishment. The same reason might explain why, in clinical trials already published, MSC transplantation failed to demonstrate substantial hyaline cartilage regeneration and clinical improvement. ${ }^{31,32}$ In the dexa-treated group the molecular and histological parameters evaluated were similar or even worse than the ones in untreated group, suggesting that dexamethasone alone could have no or adverse effects on the regeneration of hyaline cartilage. These results are consistent with data previously reported suggesting detrimental outcomes on chondrocytes exposed to steroids. ${ }^{33,34}$ Interestingly, in our case the adverse effect of dexamethasone seems to be overcome by the implantation of MSCs. Hence, the MSC/dexa-treated group showed better results than the dexa-treated group, but no statistical significant differences were observed when compared with the untreated group. The apparent inconsistency of our results might be related to (a) nonidentical group size; (b) limited reliability of ICRS score, originally settled for human samples, in rabbit samples $^{35}$; and (c) partial response to treatment.

Thus, in a young rabbit model, dexamethasone intraarticular administration after autologous MSC implantation into preestablished knee full-thickness chondral defects barely contribute to hyaline cartilage regeneration.

Among the variables that could be considered to achieve hyaline cartilage regeneration the scaffold is of great importance. HA promotes differentiation of MSCs to chondrocytes and prevents dedifferentiation of chondrocytes to fibroblasts. ${ }^{36-39}$ However, because of its high viscosity, it is difficult to tightly fix MSCs embedded in HA into the chondral defects. We do not know whether donor cells stay at the defect because we decided not to label them as it has been suggested that trackers and marker genes might influence MSC biology. ${ }^{40-43}$ This is a weakness of our study. To circumvent the former practical issue, platelet rich plasma could be added on because it acts as a sealant and also produces growth factors such as TGF- $\beta$ that might contribute to MSC chondrogenic differentiation. ${ }^{39}$ Another constraint of our study is that we have no data regarding the effect of dexamethasone and/or MSCs on inflammation during the follow-up period, because we assessed it only at the end of the study.

Though in this work we were unable to show beneficial effect of intraarticular administration of dexamethasone after MSC implantation, the conclusion is valid for the tested scheme (weekly dose of $0.25 \mathrm{mg} / \mathrm{kg}$ ) and not for other schemes, doses, or small molecules that might modify lesioned joint microenvironment in order to facilitate cartilage regeneration.

\section{Acknowledgment and Funding}

The author(s) received no financial support for the research, authorship, and/or publication of this article.

\section{Declaration of Conflicting Interests}

The author(s) declared no potential conflicts of interest with respect to the research, authorship, and/or publication of this article.

\section{Ethical Approval}

The research protocol was reviewed and approved by the Ethic Committee of Faculty of Medicine Clinica Alemana, Universidad del Desarrollo.

\section{References}

1. Yelin E. Cost of musculoskeletal diseases: impact of work disability and functional decline. J Rheumatol Suppl. 2003;68:8-11.

2. Tare R, Howard D, Pound JC, Roach HI, Oreffo RO. Tissue engineering strategies for cartilage generation - micromass and three dimensional cultures using human chondrocytes and a continuous cell line. Biochem Biophys Res Commun. 2005;333:609-21.

3. Redman SN, Oldfield SF, Archer CW. Current strategies for articular cartilage repair. Eur Cell Mater. 2005;9:23-32.

4. Risbud MV, Sittinger M. Tissue engineering: advances in in vitro cartilage generation. Trends Biotechnol. 2002;20:351-6.

5. Mobasheri A, Csaki C, Clutterbuck AL, Rahmanzadeh M, Shakibaei M. Mesenchymal stem cells in connective tissue engineering and regenerative medicine: applications in cartilage repair and osteoarthritis therapy. Histol Histopathol. 2009;24:347-66

6. Nesic D, Whiteside R, Brittberg M, Wendt D, Martin I, Mainil-Varlet P. Cartilage tissue engineering for degenerative joint disease. Adv Drug Deliv Rev. 2006;58:300-22.

7. Conget P, Minguell J. Phenotypical and functional properties of human bone marrow mesenchymal progenitor cells. J Cell Physiol. 1999;181:67-73. 
8. Minguell J, Erices A, Conget P. Mesenchymal stem cells. Exp Biol Med. 2001;226:507-20.

9. Kopen GC, Prockop DJ, Phinney DG. Marrow stromal cells migrate throughout forebrain and cerebellum, and they differentiate into astrocytes after injection into neonatal mouse brains. Proc Natl Acad Sci U S A. 1999;96:10711-6.

10. Prockop DJ. Marrow stromal cells as stem cells for nonhematopoietic tissues. Science. 1997;276:71-4.

11. Wakitani S, Goto T, Pineda SJ, Young RG, Mansour JM, Caplan AI, et al. Mesenchymal cell-based repair of large, full-thickness defects of articular cartilage. J Bone Joint Surg Am. 1994;76:579-92.

12. Tatebe M, Nakamura R, Kagami H, Okada K, Ueda M. Differentiation of transplanted mesenchymal stem cells in a large osteochondral defect in rabbit. Cytotherapy. 2005;7:520-30

13. Yan H, Yu C. Repair of full-thickness cartilage defects with cells of different origin in a rabbit model. Arthroscopy. 2007;23:178-87.

14. Han SH, Kim YH, Park MS, Kim IA, Shin JW, Yang WI, et al. Histological and biomechanical properties of regenerated articular cartilage using chondrogenic bone marrow stromal cells with a PLGA scaffold in vivo. J Biomed Mater Res A. 2008;87: 850-61.

15. Nöth U, Steinert AF, Tuan RS. Technology Insight: adult mesenchymal stem cells for osteoartritis therapy. Nat Clin Pract Rheumatol. 2008;4:371-80.

16. Steinert AF, Ghivizzani SC, Rethwilm A, Tuan RS, Evans CH, Nöth U. Major biological obstacles for persistent cell-based regeneration of articular cartilage. Arthritis Res Ther. 2007;9:213.

17. Stevens AL, Wishnok JS, White FM, Grodzinsky AJ, Tannenbaum SR. Mechanical injury and cytokines cause loss of cartilage integrity and upregulate proteins associated with catabolism, immunity, inflammation, and repair. Mol Cell Proteomics. 2009;8:1475-89.

18. Feldmann M, Brennan FM, Foxwell BM, Maini RN. The role of TNF alpha and IL-1 in rheumatoid arthritis. Curr Dir Autoimmun. 2001;3:188-99.

19. Hwang SG, Yu SS, Lee SW, Chun JS. Wnt-3a regulates chondrocyte differentiation via c-Jun/AP-1 pathway. FEBS Lett. 2005;579:4837-42.

20. McKay LI, Cidlowski JA. Molecular control of immune/ inflammatory responses: interactions between nuclear factorkappa B and steroid receptor-signaling pathways. Endocr Rev. 1999;20:435-59.

21. Derfoul A, Perkins GL, Hall DJ, Tuan RS. Glucocorticoids promote chondrogenic differentiation of adult human mesenchymal stem cells by enhancing expression of cartilage extracellular matrix genes. Stem Cells. 2006;24:1487-95.

22. Bosnakovski D, Mizuno M, Kim G, Takagi S, Okumura M, Fujinaga T. Isolation and multilineage differentiation of bovine bone marrow mesenchymal stem cells. Cell Tissue Res. 2005; 319:243-53.
23. Johnstone B, Hering TM, Caplan AI, Goldberg VM, Yoo JU. In vitro chondrogenesis of bone marrow-derived mesenchymal progenitor cells. Exp Cell Res. 1998;238:265-72.

24. Chen CW, Tsai YH, Deng WP, Shih SN, Fang CL, Burch JG, et al. Type I and II collagen regulation of chondrogenic differentiation by mesenchymal progenitor cells. J Orthop Res. 2005;23:446-53.

25. Takano T, Takigawa M, Suzuki F. Stimulation by glucocorticoids of the differentiated phenotype of chondrocytes and the proliferation of rabbit costal chondrocytes in culture. $\mathrm{J}$ Biochem. 1985;97:1093-100.

26. Martin I, Jakob M, Schäfer D, Dick W, Spagnoli G, Heberer M. Quantitative analysis of gene expression in human articular cartilage from normal and osteoarthritic joints. Osteoarthritis Cartilage. 2001;9:112-8.

27. Mainil-Varlet $\mathrm{P}$, Aigner $\mathrm{T}$, Brittberg $\mathrm{M}$, Bullough $\mathrm{P}$, Hollander A, Hunziker E, et al. Histological assessment of cartilage repair: a report by the Histology Endpoint Committee of the International Cartilage Repair Society (ICRS). J Bone Joint Surg Am.2003;85:45-57.

28. Roark EF, Greer K. Transforming growth factor-beta and bone morphogenetic protein-2 act by distinct mechanisms to promote chick limb cartilage differentiation in vitro. Dev Dyn. 1994;200:103-16.

29. Herzog W, Federico S. Considerations on joint and articular cartilage mechanics. Biomech Model Mechanobiol. 2006;5:64-81.

30. Wong M, Carter DR. Articular cartilage functional histomorphology and mechanobiology: a research perspective. Bone. 2003;33:1-13.

31. Wakitani S, Nawata M, Tensho K, Okabe T, Machida H, Ohgushi H. Repair of articular cartilage defects in the patello-femoral joint with autologous bone marrow mesenchymal cell transplantation: three case reports involving nine defects in five knees. J Tissue Eng Regen Med. 2007;1: 74-9.

32. Wakitani S, Imoto K, Yamamoto T, Saito M, Murata N, Yoneda M. Human autologous culture expanded bone marrow mesenchymal cell transplantation for repair of cartilage defects in osteoarthritic knees. Osteoarthritis Cartilage. 2002; 10:199-206.

33. Stöve J, Schöniger R, Huch K, Brenner R, Günther KP, Puhl W, et al. Effects of dexamethasone on proteoglycan content and gene expression of IL-1ßstimulated osteoarthrotic chondrocytes in vitro. Acta Orthop Scand. 2002;73: 562-7.

34. Fahey M, Mitton E, Muth E, Rosenthal AK. Dexamethasone promotes calcium pyrophosphate dihydrate crystal formation by articular chondrocytes. J Rheumatol. 2009;36:163-9.

35. Mainil-Varlet P, Van Damme B, Nesic D, Knutsen G, Kandel R, Roberts S. A new histology scoring system for the assessment of the quality of human cartilage repair: ICRS II. Am J Sports Med. 2010;38:880-90. 
36. Akmal M, Singh A, Anand A, Kesani A, Aslam N, Goodship A, et al. The effects of hyaluronic acid on articular chondrocytes. J Bone Joint Surg Br. 2005;87:1143-9.

37. HegewaldAA, Ringe J, Bartel J, Krüger I, Notter M, Barnewitz D, et al. Hyaluronic acid and autologous synovial fluid induce chondrogenic differentiation of equine mesenchymal stem cells: a preliminary study. Tissue Cell. 2004;36:431-8.

38. Chung C, Burdick JA. Influence of three-dimensional hyaluronic acid microenvironments on mesenchymal stem cell chondrogenesis. Tissue Eng Part A. 2009; 15:243-54.

39. Martínez-Zapata MJ, Martí-Carvajal A, Solà I, Bolívar I, Expósito JA, Rodriguez L, et al. Efficacy and safety of the use of autologous plasma rich in platelets for tissue regeneration: a systematic review. Transfusion. 2009;49:44-56.
40. Muller-Borer BJ, Collins MC, Gunst PR, Cascio WE, Kypson AP. Quantum dot labelling of mesenchymal stem cells. J Nanobiotechnology. 2007;5:9.

41. Harting MT, Jimenez F, Cox CS Jr. Isolation of mesenchymal stem cells (MSCs) from green fluorescent protein positive $(\mathrm{GFP}+)$ transgenic rodents: the grass is not always green(er). Stem Cells Dev. 2009;18:127-35.

42. Wang F, Dennis JE, Awadallah A, Solchaga LA, Molter J, Kuang Y, et al. Transcriptional profiling of human mesenchymal stem cells transduced with reporter genes for imaging. Physiol Genomics. 2009;37:23-34.

43. Conget PA, Minguell JJ. Adenoviral-mediated gene transfer into ex vivo expanded human bone marrow mesenchymal progenitor cells. Exp Hematol. 2000;28:382-90. 